\title{
SZADKOWSKIE OGLOSZENIE REKLAMOWE Z 1837 ROKU - ASUMPT DO KILKU UWAG NA TEMAT OSADNICTWA NIEMIECKIEGO I ROZWOJU RZEMIOSŁA TEKSTYLNEGO W SZADKU NA POCZĄTKU XIX W.
}

\begin{abstract}
Streszczenie. W 1837 r. zostało opublikowane przez władze Szadku ogłoszenie w języku niemieckim reklamujące miasto jako miejsce dogodne dla osadnictwa przemysłowego. Treść ogłoszenia wpisuje się w zakrojone na szeroką skalę działania rządu Królestwa Polskiego na rzecz rozwoju produkcji tekstylnej w Królestwie Polskim. Podstawę tego rozwoju miała stanowić napływająca z zagranicy wykwalifikowana siła robocza. Proimigracyjna polityka rządu zaowocowała pojawieniem się na ziemiach polskich wielu nowych osad przemysłowych. Niestety Szadek, w XVI w. wiodący ośrodek produkcji tekstylnej, nie znalazł się wśród tych miast które wykorzystały dobrą koniunkturę i weszły na ścieżkę szybkiego rozwoju ekonomicznego i demograficznego. Ogłoszenie z 1837 r. daje opis ówczesnego Szadku. Jednak jego efekt był niewielki i to miasto o bogatych tradycjach znalazło się wśród tych jednostek osadniczych, które na długi czas pogrążyły się w stagnacji.
\end{abstract}

Słowa kluczowe: Szadek, XIX w., osadnictwo niemieckie, industrializacja, włókiennictwo

W 1837 r. zostało opublikowane przez władze Szadku ${ }^{1}$ ogłoszenie o charakterze urzędowym, sygnowane przez burmistrza miasta oraz członka rady miejskiej o nazwisku Kosiński i ostemplowane pieczęcią z dwugłowym orłem. Ogłoszenie to przygotowane w języku niemieckim i datowane na 7 lipca 1837 r. kierowane było do potencjalnych migrantów z ziem niemieckich, przede wszystkim tych zaangażowanych w produkcję włókienniczą. Treść ogłoszenia zawierała opis ówczesnego Szadku i miała zachęcać od osiedlania w mieście.

* Tadeusz Marszał, prof. dr hab., dyrektor Instytutu Zagospodarowania Środowiska i Polityki Przestrzennej, Wydział Nauk Geograficznych, Uniwersytet Łódzki.

1 Według obowiązującego wówczas w Rosji kalendarza juliańskiego była to data 25 czerwca. 
W 1936 r. ukazał się przedruk tego ogłoszenia (przekazanego redakcji przez bliżej nieokreślonego inżyniera Michela) w 20 tomie wydawanego w Poznaniu czasopisma naukowego „Deutsche Wissenschaftliche Zeitschrift für Polen“2. Czasopismo to, redagowane w języku niemieckim przez Alfreda Lattermana ${ }^{3}$, podejmowało głównie tematykę mniejszości niemieckiej na ziemiach polskich.

Ogłoszenie reklamujące Szadek jako miejsce dogodne dla osadnictwa przemysłowego wpisuje się w zakrojone na szeroką skalę działania rządu Królestwa Polskiego na rzecz rozwoju produkcji tekstylnej. Podstawę tego rozwoju stanowić miała przede wszystkim napływająca z zagranicy wykwalifikowana siła robocza.

\section{PROIMIGRACYJNA POLITYKA RZĄDU KRÓLESTWA POLSKIEGO}

Ludność niemiecka zasiedlała ziemie polskie od stuleci, ale znaczniejszy napływ przedstawicieli tej grupy etnicznej przyniósł dopiero koniec XVIII w. i okres XIX-wiecznej industrializacji. Kolonizacja ziem Polski Środkowej początkowo była związana głównie z napływem ludności wiejskiej. Kolejne dziesięciolecia przyniosły osadzanie ludności niemieckiej na terenie miast i nowotworzonych osad rękodzielniczych.

Proimigracyjną politykę, która została zainicjonowana w okresie Księstwa Warszawskiego, po 1815 r. kontynuowały władze Królestwa Polskiego. Adresatem tej polityki była znajdująca się w trudnym położeniu ekonomicznym ludność niemiecka, poszukująca stabilniejszych źródeł utrzymania i lepszych możliwości pracy. Do migracji na ziemie polskie zachęcało podpisane 2 marca 1816 r. przez namiestnika królewskiego w Radzie Stanu, Józefa Zajączka „Postanowienie o osiedlaniu się w kraju użytecznych cudzoziemców, tak fabrykantów, rzemieślników,

2 Czasopismo wydawane w Poznaniu od 1923 r., z inicjatywy Hermanna Rauschninga (1887-1982), wspólny organ niemieckich towarzystw naukowych i kulturalnych mniejszości niemieckiej, głównie o profilu historycznym. Tekst tego ogłoszenia znajduje się również w opracowaniu O. Kossmana Deutsche in Polen: Siedlungsurkunden 16.-19. Jh., Heimatkreisgemeinschaft der Dt. aus dem Lodzer Industriegebiet, 1996, s. 432-433.

3 Alfred Latterman (ur. 23.X.1894 r. w Lesznie - zm. 3.05.1945 r., w walkach pod Berlinem), studiował germanistykę, historię i geografię na uniwersytetach w Marburgu i Wrocławiu. W 1924 r. uzyskał doktorat na podstawie rozprawy poświęconej Górnemu Śląskowi i polskim powstaniom w XIX w. Badacz i autor licznych publikacji na temat stosunków polsko-niemieckich, aktywny członek (a od 1926 r. przewodniczący) „Historische Gesellschaft für Posen” (Poznańskiego Towarzystwa Historycznego, centralnej instytucji niemieckiej nauki w Polsce), wydawca pism, m.in. Deutsche Monatshefte in Polen, Zeitschrift für Geschichte und Gegenwart des Deutschtums in Polen, Deutsche Sippenforschung in Polen, Deutsche wissenschaftliche Zeitschrift für Polen. W okresie II wojny światowej dyrektor biblioteki uniwersyteckiej w Poznaniu. Zob.: H.A. Meyer, Alfred Laterman (1894-1945), „Zeitschrift für Ostforschung” 1951, nr 1, s. 423-425 oraz R. Piejko, Biblioteka Uniwersytecka w Poznaniu w latach 1939-1945. Przyczynek do historii, „Biblioteka" 2007, nr 11(20), s. 175-182. 
jak i rolników", w którym stwierdza się: zważywszy, iż ustawa konstytucyjna Królestwa Polskiego każdemu cudzoziemcowi, skoro się wylegitymuje, równa z innymi mieszkańcami protekcje praw i używanie korzyści przez nie zaręczonych zapewnia; zważywszy, iż sprowadzanie się $i$ osiadanie $w$ Królestwie użytecznych cudzoziemców korzystny ma wplyw na podniesienie rolnictwa, fabryk, rzemiost i każdego gatunku użytecznego przemystu, chcac zachęcić takowych cudzoziemców do osiadania w tym kraju oraz usunać wszelkie trudności, które by tak $w$ przebywaniu granic, jako też $w$ obraniu miejsca zamieszkania mogli doznawać [...] postanowiliśmy i stanowimy... i dalej następuje wyliczenie ułatwień oraz przywilejów oferowanych migrującym z zagranicy rzemieślnikom, fabrykantom ${ }^{4}$ i osadnikom rolnym ${ }^{5}$.

Ustawa ta nawiązywała do wydanych w okresie Księstwa Warszawskiego dekretów ${ }^{6}$ i de facto potwierdzała zawarte w nich przywileje. Zapewniała przybyszom osiadłym na terenie Królestwa:

- zwolnienie na sześć lat od wszelkich ciężarów i podatków (pod warunkiem wypełnienia zaciągniętych zobowiązań);

- zwolnienie z obowiązku służby wojskowej imigrantów oraz ich synów;

- możliwość uzyskania paszportu na powrót do kraju ojczystego (pod warunkiem uregulowania zaległych płatności);

- zwolnienie z cła od przywożonego do Królestwa inwentarza i ruchomości.

Uzupełnieniem tych zachęt było przyjęte $\mathrm{w}$ tym samym roku (3 października 1816 r.) postanowienie o utworzeniu funduszu na rozbudowę przemysłu na ziemiach polskich, z którego środki mogły być przeznaczone m.in. na zakładanie fabryk, budowę domów dla rzemieślników i regulację osad fabrycznych, a także pożyczki i zapomogi dla „pożytecznych cudzoziemców”. Wydane 19 października 1816 r. postanowienie namiestnika mówiło, iż: fundusz ten użyty być ma na sprowadzanie fabrykantów, na udzielenie im wsparcia i na zakupienie przez

4 „Fabrykantami” nazywani byli robotnicy pracujący przy produkcji w zakładach należących do przedsiębiorców.

5 Pełny tekst postanowienia namiestnika zob. Zbiór przepisów administracyjnych Królestwa Polskiego. Wydziat spraw wewnętrznych i duchownych, cz. II Przemyst i zaktady przemyst positkujace, t. II, Warszawa 1866, s. 3-11, a także: S. Kieniewicz, Przemiany społeczne i gospodarcze w Królestwie Polskim (1815-30), Warszawa 1951, s. 283-288. Wcześniej, w 1768 r., zniesiono wprowadzone po potopie szwedzkim ograniczenia prawne wobec protestantów osiedlających się na ziemiach polskich.

6 W 1809 i 1812 roku.

7 Fundusz ten nosił nazwę ,zakładanie rękodzielni” i w latach 1821-1830 dysponował kwotą blisko 7,7 mln złp (od 370 tys. do 850 tys. złp rocznie). W latach 1823-1826 rząd uruchomił jeszcze dodatkowe fundusze wspomagające rozwój przemysłu. Od 1829 r. akcję pożyczkową mającą na celu wspieranie handlu, kredytu i przemystu narodowego przejął nowo utworzony Bank Polski. Zob. K. Bajer, Przemyst wtókienniczy na ziemiach polskich od początku XIX wieku do 1939 roku. Zarys historyczno-ekonomiczny, Łódź 1958, s. 39 i 49-50. 
rząd akcji w zakladających się fabrykach ${ }^{8}$. Szczególną wagę rząd przywiązywał do budowy urządzeń wodnych, foluszy i bielników, wspierając te inwestycje organizacyjnie i finansowo.

Kolejne udogodnienia dla imigrantów, obejmujące m.in. umiarkowany czynsz wieczysty, zapewnienie bezpłatnego drewna na budowę domów oraz pomoc w budowie kościoła ewangelickiego i mieszkania dla pastora wprowadzał dekret namiestnika królewskiego wydany 18 września 1820 r. ${ }^{9}$, na mocy którego miasta rządowe mogły być urządzone jako osady fabryczne.

21 listopada 1823 r. zostało wydane dodatkowe „Rozporządzenie o usuwaniu przeszkód przy osiedlaniu się w miastach zagranicznych fabrykantów i rzemieślników, a także o urządzaniu tych miast", w którym nie tylko potwierdzano, lecz także rozszerzano wcześniej przyznane ulgi, m.in. ułatwiając zamianę wydzierżawionego już przez osadnika gruntu. W 1824 r. zapewniono właścicieli fabryk, iż w kolejnym dziesięcioleciu nie zostanie odwołany ani zmieniony zakaz przywozu z zagranicy wyrobów sukienniczych i zostanie utrzymane prawo sprowadzania z zagranicy materiałów potrzebnych do produkcji ${ }^{10}$.

Rzemieślnicy i fabrykanci przybywający z zagranicy do Królestwa Polskiego pod względem zawodowym znajdowali się w uprzywilejowanej sytuacji, co potwierdzał zapis ustawy z 31 grudnia 1816 r. o „urządzaniu rzemiosł, kunsztów i profesji”, w której zapisano, że cudzoziemscy majstrowie do kraju przybywający wolni sa od wszelkich opłat, czeladnicy zaś obcy, chcacy zostać majstrami, podlegaja przepisom, jakie względem majstrów sa wydane ${ }^{11}$.

Kluczowy z punktu widzenia procesów industrializacji i urbanizacji był fakt, że: komisyja rządowa przeznaczyła caly szereg miasteczek, dogodnych dla rozwoju przemystowego, na osady fabryczne i obdarzyła je specyalnemi prawami i przywilejami. Zawczasu ułożono plany tych miast z oznaczeniem nowych ulic i dzielnic, tak, że koloniści zaraz po przyjeździe z zagranicy znajdowali gotowe grunta do zabudowania się, przyczem w ciagu 10 lat bezplatnie otrzymywali budulec. Około tych osad urządzano cegielnie, które za niska cenę sprzedawaty kolonistom cegłe. Mtyny skarbowe oddawano w posiadanie bezterminowe dla urzadzenia fabryk sukna ${ }^{12}$.

Jak pisał w jednym ze swych raportów R. Rembieliński, starano się na osady włókiennicze wybierać nie tylko miejsca dogodne dla osadników sukienniczych,

8 N. Gąsiorowska, Osadnictwo fabryczne, „Ekonomista” 1922, R. XXII, t. I, s. 1-40, t. II, s. 111-151, [w:] N. Gąsiorowska-Grabowska, Z dziejów przemystu w Królestwie Polskim, Warszawa 1965, s. 71.

9 Tamże, s. 74.

10 S. Koszutski, Rozwój ekonomiczny Królestwa Polskiego w ostatnim trzydziestoleciu 18701900, Warszawa 1905, s. 44.

11 S. Wiech, Ustawa o „Urządzeniu rzemiost, kunsztu i profesji” z 31 grudnia 1816 r. (próba oceny), „Kieleckie Studia Historyczne” 1994, t. 13, s. 29-41.

12 L. Janowicz, Zarys rozwoju przemystu w Królestwie Polskim, Warszawa 1907, s. 18. 
ale także miasta po większej części żadnego dochodu nie dające ${ }^{13}$ i stąd postulat, aby rząd zająt się skutecznie obmyśleniem łatwych sposobów osadzenia w swych miastach przemysłowej klasy ludzi, bez której miasta rzadowe zostana zawsze rolniczemi i mało krajowi użtecznemi ${ }^{14}$.

W Polsce Środkowej, w ówczesnym województwie kaliskim, wśród miast, które zostały wyznaczone jako potencjalne przyszłe ośrodki przemysłowe znalazły się: Kalisz, Stawiszyn, Turek, Uniejów i Warta (w obwodzie kaliskim), Koło, Konin i Słupca (w obwodzie konińskim), Brzeźnica, Pajęczno, Piotrków, Radomsko, Sulejów, Tuszyn i Wolbórz (w obwodzie piotrkowskim), Pabianice, Sieradz, Szadek i Szczerców (w obwodzie sieradzkim) oraz Wieluń i Wieruszów (w obwodzie wieluńskim) ${ }^{15}$.

\section{WERBUNEK OSADNIKÓW}

Proimigracyjna polityka rządu, zakładająca oferowanie szerokiej gamy przywilejów dla osiedlających się w Królestwie Polskim przybyszów z ziem niemieckich nie przyniosłaby spodziewanych rezultatów bez wspomagających działań promocyjnych i dotarcia do potencjalnych migrantów z informacją o korzyściach płynących z osiedlenia się w nowym miejscu.

W początkach lat 20. XIX w. rząd Królestwa Polskiego podjął prowadzoną na szeroką skalę akcję propagującą osadnictwo, które wcześniej miało charakter raczej spontaniczny. W 1824 r. przygotowano informację z opisem tworzonych i już istniejących osad przemysłowych ${ }^{16}$. Podjęta została akcja rozsyłania prospektów, odezw i zaproszeń oraz zamieszczania w prasie ogłoszeń, zachęcających do osiedlenia się w Królestwie ${ }^{17}$, za każda raza stan kwitnacy tutejszych zakładów, oraz celem podniesienia przemystu krajowego ze strony rządu świadczone do-

13 W. Ostrowski, Świetna karta z dziejów planowania w Polsce 1815-1830, Warszawa 1949, s. 47.

14 Z. Lorentz (oprac.), Trzy raporty Rajmunda Rembielińskiego prezesa Komisji Województwa Mazowieckiego z objazdu obwodu łęczyckiego w 1820 r., „Rocznik Oddziału Łódzkiego Polskiego Towarzystwa Historycznego" 1928, t. 1, s. 53.

15 Por. N. Gąsiorowska, Sekcje fabryczne (1824-1835), „Ekonomista” 1916, R. XVI, , t. I-II, s. 185-200, [w:] N. Gąsiorowska-Grabowska, Z dziejów przemysłu w Królestwie Polskim, Warszawa 1965 , s. 34.

16 A. Rynkowska, Działalność gospodarcza władz Królestwa Polskiego na terenie Łodzi przemystowej w latach 1821-1831, ŁTN, Wydz. 2, nr 5, Łódź 1951, s. 22.

17 Podobne starania czyniła administracja rosyjska - posłowie carscy w państwach niemieckich zostali zobowiązani do informowania o przyjętych ustawach o emigracji. Zob. O. Heike, Aufbau und Entwicklung der Lodzer Textilindustrie. Eine Arbeit deutscher Einwarderer in Polen für Europa, Mönchengladbach 1971, s. 56-57 [za:] W. Kessler, Rola Niemców w Łodzi, [w:] K.A. Kuczyński, B. Ratecka (red.), Niemcy w dziejach Łodzi do 1945 r., Łódź 2001, s. 13. 
brodziejstwa powtarzając ${ }^{18}$. Liczne ogłoszenia w saskiej i czeskiej prasie oraz ulotki reklamowe informowały o ulgach i przywilejach czekających na osoby decydujące się na przesiedlenie. Akcje werbunkowe były ponawiane kilkukrotnie.

Niebagatelną rolę w promowaniu migracji odegrali pierwsi przybyli do Królestwa osadnicy, którzy często stawali się mimowolnymi agentami zachęcającymi do przyjazdu swoich ziomków - przekonawszy się, że nadzieje ich zapewnione osiagają owoce, liczniejszych kolegów lub krewnych sprowadzali ${ }^{19}$.

\section{OSADNICTWO NIEMIECKIE W OKRESIE PRZEDPOWSTANIOWYM}

W sytuacji tak aktywnej polityki proimigracyjnej już w połowie roku 1824, zachęcone licznemi przywilejami rzadu tutejszego, oraz powodzeniem swoich ziomków, zgłosity się do Polski tlumy rękodzielników wyrobów bawetnianych, pragnących tę gatęź przemystu z Czech i Saksonii przeszczepić na nasza ziemię ${ }^{20}$.

W okresie przedpowstaniowym szczególne nasilenie napływu osadników przypada na lata 1824-1830. Od 1928 r. napływ imigrantów niemieckich uległ pewnemu osłabieniu, co dokumentuje zapis dokonany przez R. Rembielińskiego, iż ustały już wprawdzie owe zdarzenia nadzwyczajne, kiedy sukiennicy zagraniczni na wyścigi niemal jedni przed drugim i z rodzinnej swej ziemi do Królestwa Polskiego gromadnie niejako przenosili się, ale też niepodobna żąać, aby owa początkowa nawalna emigracja wiecznemi czasy bez końca trwać miała, bo z samej natury rzeczy wyplywa, iż temu podobne zdarzenia prędzej niż inne kres swój znaleźć muszą. Nie można jednak powiedzieć, iżby przesiedlanie się do kraju naszego zagranicznych sukienników zupetnie już ustać miało, bo niektóre miasta, jak np. Zgierz w roku nawet ostatnim dość znaczna ilościa onych przyludnionem zostato ${ }^{21}$.

18 Raport Prezesa Komisji Województwa Mazowieckiego $n r$ 2294/842 z 1.III.1827 r. Zob. J. Warężak, Raporty prezesa Komisji Województwa Mazowieckiego Rajmunda Rembielińskiego z lat 1823-1830, Warszawa 1939, s. 107.

19 G. Missalowa, Studia nad powstaniem tódzkiego okręgu przemystowego (1815-1870), t. 1 Przemyst, Łódź 1964, s. 64.

20 O. Flatt, Opis miasta Łodzi pod względem historycznym, statystycznym i przemysłowym, Warszawa 1853, s. 72.

${ }_{21}$ Z. Lorentz, Raport prezesa Komisji Wojewódzkiej Mazowieckiej o stanie przemystu włókienniczego w roku 1828, odbitka z „Rocznika Oddziału Łódzkiego Polskiego Towarzystwa Historycznego" z 1929-1930, Łódź 1930, s. 9. Zmniejszenie napływu migrantów pod koniec lat 30. zauważa także O. Flatt pisząc: powtórny prąd nawalnej emigracyi sukienników zagranicznych do kraju naszego, już w roku 1828 znacznie stabnać zacząt, powiemy nawet ustat, bo podobne wysilenia, właśnie dla swej gwałtowności, dtugotrwałemi być nie moga; z drugiej strony, konkurencya fabryk rossyjskich $i$ utrudzenia celne, wszystko to groziło upadkiem naszemu sukiennictwu, a mimo to przecież zamożni już przedsiębiercy przetrwali te burze i zapewnili swoje korzyści. Zob. O. Flatt, Opis miasta Łodzi pod względem historycznym..., s. 63-64. 
Ludność niemiecka osiadła w Królestwie Polskim przed 1830 r. najliczniej zamieszkiwała powiaty kaliski, łęczycki i piotrkowski. Praktycznie jednak na terenie Polski Środkowej nie było miasta czy większego majątku ziemskiego, do którego nie trafiliby niemieckojęzyczni przybysze. Migracja rzemieślników do sukiennictwa w latach 20. XIX w. była o tyle ułatwiona, że stanowiła kontynuację wcześniejszego napływu kolonistów rolnych z Niemiec, a nowi przybysze trafiali do regionu, gdzie od ponad trzech dziesięcioleci osiadali ich rodacy.

W pierwszym okresie największą liczbę osadników przemysłowych przyciągnął Zgierz, w którym w $1821 \mathrm{r}$. wydzielono 230 parceli pod nową osadę rękodzielniczą ${ }^{22}$. W latach 1815-1828 liczba mieszkańców tego miasta wzrosła kilkunastokrotnie do 8,9 tys. osób, a tylko między 1821 a 1828 rokiem osiadło w nim 240 majstrów sukienniczych, wśród których byli także sukiennicy przesiedlający się z sąsiednich osad przemysłowych ${ }^{23}$.

Na pierwszą połowę lat 20. XIX w. przypada także szybki rozwój Aleksandrowa, w którym w latach 1821-1822 osiadło 113 rodzin kolonistów ${ }^{24}$, a liczba majstrów sukienniczych przybyłych do miasta w latach 1821-1825, w zdecydowanej większości spoza terenu Królestwa Polskiego, sięgała 181 (w tym 119 tylko w 1822 r. $)^{25}$. Dużą liczbę cudzoziemskich sukienników przyjęły takie miasta (rządowe i prywatne) jak: Kalisz, Zduńska Wola, Sieradz, Zelów, Turek, Koło i Pabianice w województwie kaliskim oraz Bełchatów, Zgierz, Konstantynów, Ozorków, Dąbie, Ksawerów, Tomaszów Mazowiecki, Brzeziny i Łęczyca w województwie mazowieckim.

W przedpowstaniowej dekadzie wśród przybyszów z ziem niemieckich zdecydowanie dominowali osadnicy przemysłowi. Napływ fachowej siły roboczej, prawie w całości rekrutującej się z ludności pochodzenia niemieckiego, warunkował rozwój sukiennictwa ${ }^{26}$, a główne ośrodki produkcji tekstylnej były także miejscami koncentracji osadnictwa niemieckiego. Osadnicy przybywający na teren

${ }^{22}$ Zgierz w 1815 r. liczył zaledwie 558 mieszkańców i kilkadziesiąt drewnianych budynków mieszkalnych. Zob. Z. Lorentz, Raport prezesa Komisji Wojewódzkiej Mazowieckiej..., s. 13.

23 Informacja na temat pochodzenia sukienników osiedlających się w Zgierzu, zob. K. Lück, Deutsche Aufbaukräfte in der Entwicklung Polens, Plauen 1934, s. 337.

24 Zob. E. Wróbel, J. Wróbel, Aleksandrów Lódzki 1816-1831, „Mówią Wieki” 1988, nr 10, s. 17.

25 Informacja na temat pochodzenia sukienników osiedlających się w Aleksandrowie, zob. K. Lück, Deutsche Aufbaukräfte..., s. 37-338.

26 Produkcja włókiennicza przed wybuchem powstania listopadowego, zwłaszcza w województwie mazowieckim, była praktycznie w całości skupiona w rękach imigrantów z zagranicy, co wynikało m.in. z polityki prowadzonej w tym okresie przez R. Rembielińskiego, który licząc na spolonizowanie ludności cudzoziemskiej był przeciwny uprzemysłowieniu ludności krajowej obawiając się, że zostanie ona w ten sposób oderwana od zajęć rolniczych. Zob. Z. Lorentz (oprac.), Trzy raporty Rajmunda Rembielińskiego..., s. 58. 
Polski Środkowej w okresie przedpowstaniowym pochodzili przede wszystkim z Saksonii, Wirtembergii (Szwabii), Śląska, Czech, Meklemburgii, Prus oraz Hesji, a także z terenu Wielkiego Księstwa Poznańskiego.

\section{OSADNICTWO NIEMIECKIE PO POWSTANIU LISTOPADOWYM}

Istotny wpływ na sytuację osiadłej na ziemiach polskich mniejszości niemieckiej miało powstanie listopadowe. Jego skutkiem był kryzys ekonomiczny lat 1830-1834, który pozbawił pracy znaczną część napływowej ludności niemieckiej. Dla wielu sukienników wybuch powstania oznaczał katastrofę gospodarczą. Rząd Królestwa Polskiego doskonale zdawał sobie sprawę z konsekwencji ekonomicznych powstania, co potwierdza pismo kierowane 17 stycznia 1831 r. do Komisji kaliskiej i mazowieckiej, w którym stwierdza się, iż teraźniejsze wypadki w kraju pociagnęty stagnację w handlu, skutkiem czego fabryki krajowe, mając utrudniony odbyt na swe wyroby, moga doznawać chwilowego braku gotowizny na utrzymanie w czynnym ruchu fabryk, zaś życzeniem Rzadu jest, by do czasu spokojniejszego utrzymać przynajmniej czeladź i ludność pracujaca w fabrykach ${ }^{27}$.

Działania podejmowane przez władze rosyjskie, a zwłaszcza wprowadzenie granicy celnej miedzy Królestwem a Cesarstwem Rosyjskim, spowodowały wyraźne i trwające aż do połowy lat 30. nasilenie wyjazdów osadników niemieckich, przede wszystkim z większych ośrodków produkcyjnych.

W 1833 r. nastąpiło pewne zaostrzenie przepisów regulujących napływ imigrantów na teren Królestwa Polskiego. 23 kwietnia tego roku został wydany dekret zmieniający zasady osiedlania się cudzoziemców w Królestwie Polskim: ${ }^{28}$

- koloniści mogli się osiedlać pod warunkiem podania zawodu, stanu majątkowego, pochodzenia, miejsca docelowej migracji oraz uzyskania zezwolenia na opuszczenie ojczyzny;

- migrujący cudzoziemcy na podstawie paszportów podlegali kwalifikacji przez Komisję Rządową Spraw Wewnętrznych;

- koloniści nie otrzymywali zapomóg pieniężnych i zwolnień z ulg celnych (ocleniu nie podlegał tylko dobytek osobisty);

- koloniści przez okres sześciu lat byli zwolnieni od ciężarów publicznych (czynszu); wraz z synami byli zwolnieni także od służby wojskowej.

27 N. Gąsiorowska, Osadnictwo fabryczne..., s. 122. Wydarzenia lat 1830-1831 miały dramatyczny wpływ nawet na tak prężne zakłady jak Tytusa Kopischa w Łodzi, który pisał: przez wypadki rewolucyjne poniosłem znaczne straty, które majątek mój zrujnowaty [...] tak dalece, że nawet [fabryka moja] jest zupetnie bezczynna i zamknięta. Zob. F. Friedman, Początki przemystu w Lodzi 1823-1830, „Rocznik Łódzki” 1933, t. 3, s. 171.

28 E. Boss, Sprawa robotnicza w Królestwie Polskim w okresie paskiewiczowskim 1831-1855, „Rozprawy Historyczne Towarzystwa Naukowego Warszawskiego” 1931, t. X, z. 1, s. 134. 
Wydane 10 maja 1833 r. postanowienie Rady Administracyjnej nakazywało osiedlającym się w miastach lub na gruntach rządowych cudzoziemcom ${ }^{29}$ :

- udowodnienie wykonywania zawodu rzemieślnika, fabrykanta lub rolnika;

- złożenie deklaracji o posiadanym majątku z podaniem liczby osób w rodzinie;

- $\quad$ przedstawienie opinii stosownych władz o nienagannym trybie życia;

- zgłoszenie się do Komisji Rządowej Spraw Wewnętrznych o przydział miejsca zamieszkania.

Wymagania, które pojawiły się w opublikowanych w 1833 r. przepisach migracyjnych, choć zapewne w pewnym stopniu utrudniały migrację, nie miały większego wpływu na zahamowanie osadnictwa niemieckich rolników i rzemieślników. Zadecydowała o tym, mająca nadal charakter proimigracyjny, polityka rządu Królestwa Polskiego, który - przy bardziej selektywnym podejściu do osadnictwa cudzoziemców - kontynuował starania mające na celu pozyskiwanie przybyszy z terenów położonych za zachodnią granicą państwa. Już wkrótce po upadku powstania listopadowego w prasie ukazującej się w Wirtembergii i Badenii zostały zamieszczone kolejne informacje zachęcające do migracji na ziemie polskie.

Kryzys po upadku powstania listopadowego spowodowany restrykcyjną polityką Rosji i wprowadzeniem ceł na eksport sukna do tego kraju okazał się krótkotrwały i w dłuższej perspektywie czasowej nie miał większego wpływu na rozwijającą się w ośrodkach Polski Środkowej produkcję przemysłową. Wraz z poprawą sytuacji gospodarczej masowe, mające żywiołowy charakter w okresie powstania i pierwszych latach popowstaniowych przemieszczenia ludności niemieckiej z osad przemysłowych Polski Środkowej szybko uległy wyraźnemu zahamowaniu, a szereg ośrodków produkcyjnych zaczęło notować ponowny napływ osadników i przyrost mieszkańców. Fabrykanci miejscowi z wolna podnosili swe zakłady, zaczynali je wprowadzać w ruch, a obcy, zachęceni przyktadem, że rząd cudzoziemcom klęskami rewolucji zniszczonym nie odmawiał opieki i wsparcia, ściagali z zagranicy na miejsce zarażonych ,,zaburzeniami” $i$ wysztych z kraju osadników ${ }^{30}$. Co więcej: Czasowy zastój w wytwarzaniu, wywołany trudnościa zbytu na rynkach rosyjskich, okazat pewien pożyteczny wptyw na przemyst polski. Fabrykanci zmuszeni okolicznościami nie tylko do szukania nowych rynków zbytu, ale i do wprowadzania ulepszeń w fabrykacyi. Tem samem podnieśli do pewnego stopnia zarówno technikę wytwarzania, jak $i$ sposoby zbytu wyrobów swoich. Wielu z nich, nie znajdując zbytu, przerobiło swoje warsztaty, przystosowujac je do produkcyi tkanin bawetnianych, inni ulepszyli swoje wyroby, pragnac $w$ ten sposób konkurować z fabrykantami rosyjskimi, niektórzy zaczęli wyrabiać gładkie nieworsowane tkaniny wetniane, jakich w Rosyi wówczas nie wyrabiano.

29 Zbiór przepisów administracyjnych..., s. 31-37, a także G. Missalowa, Studia nad powstaniem łódzkiego okręgu przemysłowego (1815-1870), t. 1 Przemyst, Łódź 1964, s. 94.

30 N. Gąsiorowska, Sekcje fabryczne..., s. 48. 
Wytwarzanie tkanin takich, pierwiastkowo wyłacznie sprowadzanych z zagranicy, przybrało w Królestwie Polskiem znaczne rozmiary ${ }^{31}$.

Lata 1837-1844 przyniosły kolejną falę migracji rzemieślników ${ }^{32}$, którzy kierowali się przede wszystkim do Łodzi i otaczających to miasto ośrodków produkcyjnych. Główne kierunki wzmożonego napływu migrantów w drugiej połowie lat 30. i pierwszej połowie lat 40. XIX w., to oprócz Prus także Saksonia (zwłaszcza wschodnia Saksonia, okolice Kamienicy Saskiej i Drezna, gdzie w pobliżu granicy z Czechami był wykształcony silny okręg włókienniczy) i Czechy. Wśród migrantów z Saksonii byli prawie wyłącznie wykwalifikowani tkacze oraz fachowcy znający się na maszynach włókienniczych i tylko bardzo nieliczną grupę stanowili niewykwalifikowani wyrobnicy. Napływało również wielu rzemieślników z Czech i Moraw, głównie z północnych sudeckich terenów przylegających do granicy saskiej, z okolic Rumburka, Georgswalde, Grottau i Kamienicy Czeskiej. Był to region, w którym zdecydowanie przeważała ludność niemiecka, toteż większość przybyszów stanowili przedstawiciele tej narodowości. Osadnicy napływający z Czech, w przeciwieństwie do tych z Saksonii, nie zawsze posiadali wysokie kwalifikacje zawodowe i pod tym względem była to migracja o wiele bardziej zróżnicowana, z dużym udziałem wyrobników i osób ubogich.

Od połowy lat 30. liczba migrantów w osadach fabrycznych rosła tak szybko, że pod koniec tego dziesięciolecia gubernator mazowiecki Franciszek Potocki mógł już napisać, iż interesy fabryczne codziennie zwiększały się z powodu przybywających fabrykantów z zagranicy i wzrastajacego ich dobrobytu ${ }^{33}$. Załamanie napływu kolonistów przemysłowych spowodował dopiero kryzys z połowy lat 40., a z niektórych ośrodków produkcyjnych nastąpił nawet pewien ich odpływ. Napływ nowych migrantów niemal całkowicie ustał, a rząd podjął działania mające na celu wydalenie z kraju pozostających bez pracy osadników przebywających w dotkniętych bezrobociem ośrodkach włókienniczych. Zgodnie z zrządzeniem gubernatora warszawskiego należało wszystkich podmajstrów, czeladź i robotników fabrycznych tudzież rzemieślników cudzoziemców, za paszportami w kraju tutejszym przebywających, roboty nie majacych, wyprawić za granicę bez względu, czy

31 L. Janowicz, Zarys rozwoju przemystu..., s. 28-29.

32 G. Missalowa, Studia nad powstaniem tódzkiego okręgu przemysłowego (1815-1870), t. 1 Przemyst, Łódź 1964, s. 76, 83.

33 N. Gąsiorowska, Sekcje fabryczne (1824-1835), „Ekonomista” 1916, R. XVI, t. I-II, s. 185-200; N. Gąsiorowska-Grabowska, Z dziejów przemystu w Królestwie Polskim, Warszawa 1965, s. 64. 
im już paszporta wyexpirowały lub nie. Dla ułatwienia im możności dostania się za granice dać każdemu z nich tytutem wsparcia na drogę rbs 2 i bilet bezplatny na jazdę koleją żelazna do granicy ${ }^{34}$.

\section{SZADEK JAKO OŚRODEK SUKIENNICZY W POCZĄTKACH XIX W.}

W XVI w. znajdujący się na wschodnich połaciach Wielkopolski okręg sieradzko-łęczycki był jednym z głównych regionów produkcji sukienniczej na ziemiach polskich. Szadek, obok Brzezin, był najznaczniejszym ośrodkiem sukienniczym w tej części kraju ${ }^{35}$. W połowie XVI stulecia w mieście funkcjonowały dwa folusze, a w produkcję sukna zaangażowane było blisko 100 zakładów rzemieślniczych. Jeszcze w 1616 r. w Szadku było 90 majstrów sukienniczych, ale już lata 20. XVII w. - okres epidemii, pożarów i strat wojennych - przyniosły załamanie gospodarki i upadek rzemiosła sukienniczego ${ }^{36}$.

Szanse na ponowny rozwój produkcji tekstylnej w mieście przyniósł, wraz z napływem do Królestwa Polskiego sukienników z zagranicy, początek XIX w.

Jak w te XIX-wieczne procesy rozwojowe wpisał się Szadek - niegdyś miasto królewskie, a planach rządu Królestwa Polskiego wpisane jako potencjalny rządowy ośrodek rozwoju przetwórstwa tekstylnego? Czy miasto nawiązało do tradycji sprzed dwóch stuleci, gdy było znaczącym ośrodkiem życia gospodarczego na ziemiach polskich?

W 1791 r. wśród 40 rzemieślników prowadzących działalność w Szadku był tylko jeden sukiennik. Ponieważ ten sam raport sporządzony przez władze miejskie Szadku mówi o jednym przybyszu Niemcu, można sądzić, że to właśnie on jako jedyny trudnił się sukiennictwem w Szadku pod koniec XVIII w. ${ }^{37}$ W 1810 r. Szadek, miasto rządowe, liczył 151 domów i 1149 mieszkańców. 45 placów pozostawało niezabudowanych, co było wynikiem m.in. dotykających miasto pożarów ${ }^{38}$.

Okres względnej pomyślności miasta przypada na lata Księstwa Warszawskiego, gdy od 1809 r. do 1815 dostateczna liczba sukienników z kraju pruskiego była się

34 Pismo gubernatora cywilnego warszawskiego Laszczyńskiego do burmistrza m. Pabianic Bartkiewicza 7.V.1848 r., WAPŁ 192/75, nlb. [za:] G. Missalowa (oprac.), Źródta do historii klasy robotniczej okręgu łódzkiego. Materiały do historii miast, przemysłu i klasy robotniczej w okręgu tódzkim, t. I, Warszawa 1957, s. 389.

35 Znaczącymi ośrodkami sukienniczymi były także Sieradz, Warta i Kalisz.

36 W 1629 r. w Szadku pozostało tylko 40 sukienników. Więcej na temat sukiennictwa w Szadku w XV-XVII w. Zob. T. Marszał, Szadek jako ośrodek sukienniczy w XV-XVII w., „Biuletyn Szadkowski” 2014, t. 14, s. 39-58 oraz K. Bajer, Przemyst włókienniczy na ziemiach polskich..., s. 20-22.

37 J. Goldberg, Studium historyczno-urbanistyczne Szadku, Łódź 1961, mpis, s. 14-15.

38 W pożarze z 1809 r., który zniszczył cały kwartał między ulicami Stodolnianą, Przatowską, Bobownią i Uniejowską spłonęło 13 domów z przybudówkami i stajniami oraz 3 stodoły. W wyniku pożaru w 1816 r. spalone zostały 3 domy i 16 stodół. Zob. E. Hryniak, Studium historyczno-konserwatorskie miasta Szadek, Kielce 1989, mpis, s. 18. 
zgromadzita, a nawet w roku 1818 folusz już byli ugodzili ${ }^{39}$. W 1816 r. w Szadku znajduje się familii 40 - głównie spośród fabrykantów (połowa analfabeci) ${ }^{40}$ - były to osoby wyznania ewangelickiego w większości przybyłe do miasta najprawdopodobniej już w okresie zaboru pruskiego w ramach prowadzonej przez rząd pruski akcji osiedleńczej w Prusach Południowych ${ }^{41}$. Ale już koniec drugiej dekady XIX w. przyniósł załamanie ledwie co zapoczątkowanego rozwoju gospodarczego miasta i jak miasto Szadek znacznie od roku 1809 do roku 1815 zaczęło wzrastać tak też od roku ostatniego zaczęło upadać, a to z tych powodów: raz przez włączenie powiatu szadkowskiego do obwodu sieradzkiego i wyprowadzenie się władzy administracyjnej do miasta Sieradza. Po wtóre [...] ustanowiony szarwark w roku 1816 wszystkich mimo cierpień powynosit, majętniejszych do Prus, a uboższych do dóbr szlacheckich ${ }^{42}$.

I choć w w pierwszych latach Królestwa Polskiego podejmowano kolejne próby sprowadzenia do Szadku fabrykantów to nie były one zbyt skuteczne, gdyż w 1819 r. w mieście prowadziło działalność zaledwie dwóch sukienników ${ }^{43}$. W 1820 r. liczba sukienników i farbiarzy w Szadku wzrosła do $10^{44}$.

Na przełomie drugiego i trzeciego dziesięciolecia XIX w. drobne rzemiosło zajmujące się produkcją tkanin i płócien istniejące $\mathrm{w}$ wielu ośrodkach miejskich Polski Środkowej było ciągle nastawione głównie na zaspokojenie potrzeb lokalnych ${ }^{45}$. Według urzędowego ,wykazu fabryk sukna w Królestwie Polskim znajdujących się w 1821 r." w Szadku znajdowało się siedem warsztatów sukienniczych (w Zduńskiej Woli 17) ${ }^{46}$, należących do siedmiu przybyłych najprawdopodobniej ze Śląska majstrów sukienniczych narodowości niemieckiej. Były to bardzo niewielkie zakłady produkcyjne, w których w 1823 r. wyprodukowano zaledwie

39 J. Goldberg, Studium historyczno-urbanistyczne Szadku, Łódź 1961, mpis, s. 23 [za:] M. Kulesza, Rozwój przestrzenny $i$ wspótczesna struktura morfogenetyczna Szadku, „Biuletyn Szadkowski” 2003, t. 3, s. 65.

40 AGAD Komisja Województwa Kaliskiego sygn. KWK 685 [za:] E. Hryniak, Studium historyczno-konserwatorskie..., s. 96.

${ }^{41}$ Na terenie Prus Południowych kolonistów osadzano w domenach państwowych utworzonych z sekularyzowanych dóbr kościelnych i starostw skonfiskowanych za udział dzierżawców w powstaniu kościuszkowskim. Początkowo starano się zasiedlać opuszczone gospodarstwa chłopskie, a z czasem organizowane przez administrację pruską osadnictwo objęło dawne dobra skarbu polskiego.

42 Urzędowy opis Szadku cytowany w J. Goldberg, Studium historyczno-urbanistyczne..., s. 19.

43 W 1919 r. w Szadku było łącznie 49 rzemieślników, najwięcej szewców - 18, krawców - 8, rzeźników - 8, piekarzy - 6 i garncarzy - 6. Zob. AGAD KRSW 1785 [za:] E. Hryniak, Studium historyczno-konserwatorskie..., s. 19.

44 J. Goldberg, Studium historyczno-urbanistyczne..., s. 20.

45 A. Różański, Próba określenia liczby imigrantów niemieckich przybylych na teren Królestwa, „Roczniki Dziejów Społecznych i Gospodarczych” 1948, t. 10, s. 195-199.

${ }^{46}$ AGAD, Kancelaria Nowosilcowa, sygn. 551 [za:] G. Missalowa, Studia nad powstaniem łódzkiego okręgu przemysłowego (1815-1870), t. 1 Przemyst, Łódź 1964, s. 17. 
156 postawów sukna, co oznacza, iż produkcja jednego zakładu rzemieślniczego średnio wynosiła 22-23 postawy rocznie, podczas gdy w sąsiedniej Zduńskiej Woli średnia wielkość produkcji w tym samym roku była blisko trzykrotnie większa i oscylowała w granicach 64-65 postawów ${ }^{47}$.

Rząd Królestwa Polskiego, podejmując starania ściągnięcia „użytecznych cudzoziemców", kolportował ogłoszenia zachęcające cudzoziemców do osiedlania się w miastach rządowych. Z inicjatywy prezesa Komisji Województwa Mazowieckiego J. Radoszewskiego ukazała się ulotka nosząca datę 15 sierpnia 1823 r., w której wśród miast przeznaczonych na osady rękodzielnicze wymieniany jest Szadek ${ }^{48}$.

W połowie lat 20. do Szadku przybyło trzech majstrów i dwóch czeladników produkujących wyroby płócienne. W $1825 \mathrm{r}$. w mieście pojawił się folusz. Jednak w przeciwieństwie do wielu innych ośrodków regionu Szadek nie zanotował znaczniejszego napływu rzemieślników i pozostawał na marginesie szybko dokonujących się przemian gospodarczych.

W tym samym okresie 1821-1825 w Zduńskiej Woli, liczba majstrów zajmujących się produkcją tekstylną wzrosła z 17 do 202, a liczba warsztatów z 17 do 210 (por. tab. 1). To zestawienie z nieopodal położoną, znajdującą się w rękach prywatnych i w początkach lat 20. XIX w., nie posiadająca praw miejskich Zduńską Wolą jest o tyle istotne, że rozwój tej jednostki osadniczej stanowił istotny element zmian w hierarchii osadniczej w ,szadkowskiej” części regionu łódzkiego.

Tablica 1. Produkcja wyrobów wełnianych, bawełnianych i lnianych w Szadku oraz Zduńskiej Woli w latach 1821-1825*

\begin{tabular}{|c|c|c|c|c|c|c|}
\hline \multirow{2}{*}{ Rok } & \multicolumn{2}{|c|}{ Liczba majstrów } & \multicolumn{2}{c|}{ Liczba czeladników } & \multicolumn{2}{c|}{ Liczba warsztatów } \\
\cline { 2 - 7 } & Szadek & $\begin{array}{c}\text { Zduńska } \\
\text { Wola }\end{array}$ & Szadek & $\begin{array}{c}\text { Zduńska } \\
\text { Wola }\end{array}$ & Szadek & $\begin{array}{c}\text { Zduńska } \\
\text { Wola }\end{array}$ \\
\hline \multicolumn{7}{|c|}{ Produkcja wyrobów wełnianych } \\
\hline 1821 & 7 & 17 & $\mathrm{x}$ & $\mathrm{x}$ & 7 & 17 \\
\hline 1823 & 7 & $126^{\mathrm{a}}$ & - & 78 & 7 & 122 \\
\hline 1824 & 3 & 144 & - & 119 & 3 & 119 \\
\hline 1825 & 6 & 144 & 1 & 119 & 5 & 119 \\
\hline
\end{tabular}

${ }^{47}$ W 1823 r. produkcja sukna w 122 warsztatach sukienniczych Zduńskiej Woli wyniosła 7893 postawów sukna. Zob. K. Badziak, K. Woźniak (oprac.), Materiały do dziejów uprzemystowienia Królestwa Polskiego. Raporty prezesów Komisji Województwa Kaliskiego z lat 1823-1832, Łódź 1998 , tab. 2.

48 Ulotka ta sygnowana przez J. Radoszewskiego i komisarza fabryk Dunina zawierała informacje o formach wsparcia udzielanego kolonistom. Zob. G. Missalowa, Studia nad powstaniem łódzkiego okręgu przemysłowego (1815-1870), t. 1 Przemyst, Łódź 1964, s. 90. 
Tablica 1. (cd.)

\begin{tabular}{|c|c|c|c|c|c|c|}
\hline \multirow{2}{*}{ Rok } & \multicolumn{2}{|c|}{ Liczba majstrów } & \multicolumn{2}{c|}{ Liczba czeladników } & \multicolumn{2}{c|}{ Liczba warsztatów } \\
\cline { 2 - 7 } & Szadek & $\begin{array}{c}\text { Zduńska } \\
\text { Wola }\end{array}$ & Szadek & $\begin{array}{c}\text { Zduńska } \\
\text { Wola }\end{array}$ & Szadek & $\begin{array}{c}\text { Zduńska } \\
\text { Wola }\end{array}$ \\
\hline \multicolumn{7}{|c|}{ Produkcja wyrobów bawełnianych i lnianych } \\
\hline 1824 & - & 46 & - & 40 & - & $79^{\mathrm{b}}$ \\
\hline 1825 & 3 & 58 & 2 & 40 & 3 & 91 \\
\hline
\end{tabular}

* $\quad$ wielkość produkcji podana w postawach (1 postaw $=$ średnio 32 łokcie)

a $\quad$ w tym 1 majster farbiarski, 2 majstrów postrzygaczy, 1 folusznik

b w tym 37 warsztatów do produkcji płócien i 42 warsztaty do produkcji tkanin bawełnianych

Źródło: K. Badziak, K. Woźniak (oprac.), Materiały do dziejów uprzemysłowienia Królestwa Polskiego..., tab. 1-3 oraz G. Missalowa (oprac.), Źródła do historii klasy robotniczej okręgu łódzkiego..., s. 7.

\section{Działalność handlarzy i nakładców}

Rozwojowi sukiennictwa towarzyszyła działalność handlarzy suknem i wełną, czym zajmowali się głównie Żydzi. W Szadku kluczową postacią był Faybuś Opatowski, który podjął działalność handlową w latach 1818-1819. Był on także dzierżawcą dochodów z wagi miejskiej (a czasowo również dochodów z rzezi i handlu solą). Zachował się dokument mówiący, iż w 1824 r. na potrzeby lokalnych rzemieślników F. Opatowski zakontraktował u hodowcy owiec z Ralewic dostawę wełny, która tu do Szadku przystawiona i na wage miejska odważona będzie ${ }^{49}$. Słaby rozwój szadkowskiego rękodzielnictwa sukienniczego skłonił tego przedsiębiorczego człowieka do przeprowadzki w $1825 \mathrm{r}$. do prężnie rozwijającego się ośrodka przetwórstwa tekstylnego w Zduńskiej Woli w celu prowadzenia handlu suknem i innymi rzeczami oraz zawarcia umowy z dziedzicem miasta, w której zobowiązywał się do wystawienia „ciepłych ram” (suszarni sukna). Pod koniec lat 20. F. Opatowski stał się jednym z największych nakładców organizujących w powiecie szadkowskim produkcję sukienniczą ${ }^{50}$. Był właścicielem kilku domów

49 Akta notarialne pow. szadkowskiego za rok 1824, nr 428, [za:] Missalowa G., Studia nad powstaniem łódzkiego okręgu przemysłowego (1815-1870), t. 1 Przemyst, Łódź 1964 , s. 256.

50 Działalność F. Opatowskiego jako nakładcy dokumentuje m.in. jedna z wielu zawieranych przez niego umów z niemieckimi kolonistami - 16.10.1826 r. taka umowa została zawarta z czterema sukiennikami Josephem Ressel, Gottfriedem Dehnke, Carlem Samuelem Schmidt oraz Erenfrydem Geldner, którzy zobowiązuja się dla Fajbusia Opatowskiego wyrabiać sukno [...] a to z wetny, jaka Opatowski dawać będzie. Zob. G. Missalowa (oprac.), Źródta do historii klasy robotniczej okręgu łódzkiego..., s. 124. 
w rodzinnym Szadku ${ }^{51}$. Na mniejszą skalę handlem wełną na potrzeby prowadzonych przez niemieckich kolonistów warsztatów sukienniczych w drugiej połowie lat 20. w Szadku zajmowali się też Józef Kopel, który od 1829 r. posiadał własny skład wełny ${ }^{52}$ i Mendel Lewin ${ }^{53}$.

Pomimo silnej konkurencji ze strony wielu szybko rozwijających się osad włókienniczych województwa kaliskiego, w końcu lat 20. Szadek nadal pozostawał ośrodkiem, w którym prowadzona była, wprawdzie na niewielką skalę, produkcja tekstylna. Dokumentuje to pismo z 3 lutego 1830 r. skierowane m.in. do Szadku (a także Lutomierska, Pabianic, Łasku i Zduńskiej Woli), w którym Komisja Wojewódzka nakazała następne rozporzadzenie wydać urzędom municypalnym $i$ wójtowskim gmin tych, gdzie zakłady fabryczne egzystuja przypominające czeladnikom i robotnikom fabrycznym o obowiązku spokojnego życia i zakazie przerywania pracy oraz nakazujące ażeby czeladzi porządnej i pilnej oraz spokojnie się prowadzacej każden burmistrz wszelka pomoc i protekcję udzielat ${ }^{54}$.

\section{Nowe Miasto}

Pierwsza połowa XIX w. przyniosła częściową regulację miasta. Najprawdopodobniej w połowie lat 20. w strukturze przestrzennej Szadku pojawiła się nowa jednostka morfogenetyczna - „Nowe Miasto" przylegające od wschodu do średniowiecznej tkanki miejskiej ${ }^{55}$. Wiele wskazuje, iż wytyczone tu działki zostały wpisane $\mathrm{w}$ istniejącą już siatkę ulic z przeznaczeniem dla przybywających ze Śląska tkaczy. Nowa dzielnica została zaprojektowana dla fabrykantów, a w punkcie gdzie kończa się ulice Warszawska i Piotrkowska, uformowany zostat nowy, obszerny rynek i nowa wychodzaca z rogu ulica nazwana fabryczna, przy której [...] utworzono kilkadziesiąt placów budowlanych, które dla fabrykantów tamże osiedlać się majacych przeznaczone zostały ${ }^{56}$. Działki miały szerokość około

${ }^{51}$ Już w 1827 r. Faybuś Opatowski w znacznej ilości handel sukna zduńsko-wolskiego utrzymuje i takowego eksportacja zagranice do Rosji i Chin popiera. W 1830 r. F. Opatowski założył własną „fabrykę” sukna (do której sprowadził maszynę tkacką o wartości 7,2 tys. złp), a w 1837 r. uruchomił manufakturę sukienniczą w Zduńskiej Woli. Zob. J. Śmiałowski, Zduńska Wola. Monografia miasta do 1914 r., Łódź 1974, s. 36, 46, 60, 104.

52 J. Stulczewski, Żydzi w Szadku - rys historyczny, ,Biuletyn Szadkowski” 2010, t. 10, s. 144.

53 J. Śmiałowski, Zduńska Wola. Monografia miasta..., s. 57.

${ }^{54}$ G. Missalowa (oprac.), Źródła do historii klasy robotniczej okręgu tódzkiego..., s. 589-591; G. Missalowa, Studia nad powstaniem łódzkiego okręgu przemysłowego (1815-1870), t. 2 Klasa robotnicza, Łódź 1967, s. 145-146.

55 Według jednej z hipotez Nowe Miasto powstało już w XVI w. i było związane z ówczesnym rzemiosłem sukienniczym, które koncentrowało się wzdłuż ulic Warszawskiej i Piotrkowskiej.

56 AGAD KSRW, sygn. 1787 [za:] M. Kulesza, Rozwój przestrzenny..., s. 66. 
4 prętów (ok. $17 \mathrm{~m}$ ). W dużej części nie zasiedlone tereny Nowego Miasta, były wcześniej użytkowane przez mieszczan szadkowskich jako ogrody ${ }^{57}$.

\section{Kościół ewangelicko-augsburski}

Atutem przyciągającym do miasta ludność narodowości niemieckiej, w ogromnej większości wyznania ewangelicko-augsburskiego, miało też być zapewnienie odpowiedniego budynku z przeznaczeniem na dom modlitwy. Początkowo miasto zamierzało wykupić wystawiony w okresie zaboru pruskiego magazyn wojskowy $i$ adaptować go na ten $\operatorname{cel}^{58}$. Od $1818 \mathrm{r}$. szadkowscy luteranie czasowo użytkowali rzymsko-katolicki kościół św. Ducha w Szadku, który ostatecznie został przekazany ewangelikom w $1839 \mathrm{r}^{59}$

\section{SZADEK POŁOWY LAT 30. XIX W. W OGŁOSZENIU REKLAMOWYM}

Tytułowy werset wspomnianego ogłoszenia z 7 lipca 1837 r. zawiera określenie dokładnego usytuowania w przestrzeni administracyjnej tego jak zaznaczono „królewskiego" miasta: Królestwo Polskie, gubernia kaliska ${ }^{60}$, obwód sieradzki, powiat szadkowski. Treść ogłoszenia była wyrazem woli nie tylko władz Szadku, ale także jego mieszkańców i właścicieli nieruchomości (budynków i ziemi) w mieście, którzy adresowali je do wszystkich zagranicznych przedsiębiorców planujących osiąść w Królestwie. Ogłoszenie to miało stanowić zachętę do osiedlenia się w mieście i zapewniało potencjalnych przybyszy o gwarancjach swobód obywatelskich i bezpieczeństwie osobistym, jak również w zakresie posiadanego mienia.

Kluczowa część ogłoszenia poświęcona jest opisowi miasta według stanu na połowę lat 30. XIX w. Charakterystyka położenia Szadku w przestrzeni regionu zawiera odwołanie do Zduńskiej Woli. Jest to o tyle zrozumiałe, że miasto to dzięki inicjatywie jej właściciela Stefana Złotnickiego już pod koniec drugiego dziesięciolecia notowało masowy napływ tkaczy ze Śląska, Saksonii i Czech (w 1824 r. było tu już blisko 150 sukienników dysponujących około 140 warsz-

57 Z. Głąb, Szadek w świetle dziewiętnastowiecznych źródel kartograficznych, Wydział Filozoficzno-Historyczny, Uniwersytet Łódzki, Łódź 2005, praca magisterska, mpis, s. 94.

58 AGAD KRSW sygn. 6475 ulb. [za:] E. Hryniak, Studium historyczno-konserwatorskie..., s. 19.

59 AGAD KWK sygn. 685 [za:] E. Hryniak, Studium historyczno-konserwatorskie..., s. 96-97 oraz J. Stulczewski, Ewangelicy w okolicy Szadku i Zduńskiej Woli w XIX-XX w., „Biuletyn Szadkowski” 2009, t. 9, s. 89.

${ }_{60} 23$ lutego/7 marca 1837 r. decyzją cara Mikołaja I województwo kaliskie zostało przemianowane na gubernię kaliską. 
tatami tkackimi, w 1825 r. uzyskało prawa miejskie, w kolejnych latach stało się znaczącym ośrodkiem przemysłowym i w 1830 r. liczyło 3,6 tys. mieszkańców). Z czasem w samej Zduńskiej Woli zaznaczył się brak wolnych działek dla napływających tkaczy i już w drugiej połowie lat 20. napływających rzemieślników lokowano na terenach przylegających do miasta ${ }^{61}$. Położenie Szadku w sieci osadniczej regionu doprecyzowuje podana w ogłoszeniu odległość miasta nie tylko od przemysłowego ośrodka Zduńskiej Woli, która wynosi 1 milę, ale także od najbliższego miasta okręgowego, Sieradza - 2 mile i od stolicy guberni Kalisza - 8 mil. Te odległości podane w milach nie mają żadnego odniesienia do współczesnej miary długości i mają charakter historyczny - mila polska w tamtym czasie liczyła 7 wiorst, tj. ok. $8,53 \mathrm{~km}^{62}$. Informacją przyciągającą zainteresowanych osiedleniem w Szadku rzemieślników miało być także jego położenie w suchej i czystej okolicy oraz niewielka odległość od dwóch pobliskich „miast handlowych": Łasku - 2 mile i Lutomierska - 2 mile.

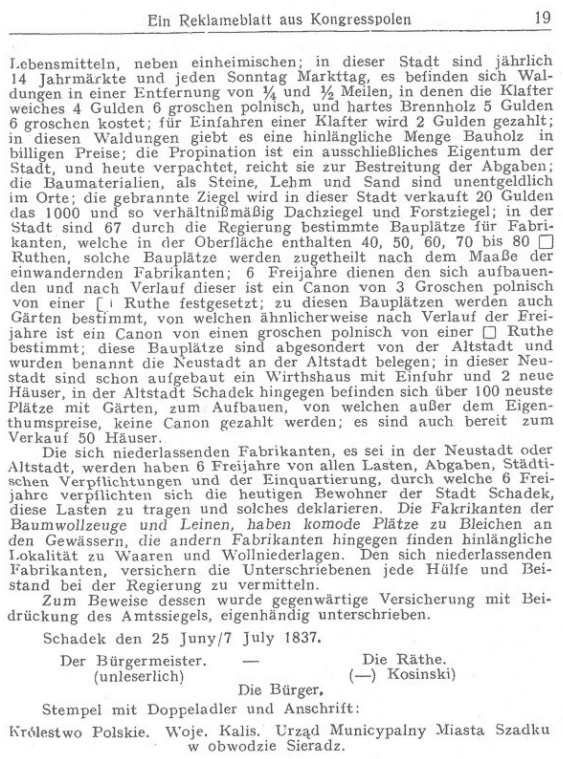

Fot. 1. Ogłoszenie promujące Szadek jako miejsce osiedlenia fabrykantów z 7 lipca $1837 \mathrm{r}$. Źródło: Mitgeteilt von Ing. Michel, „Deutsche Wissenschaftliche Zeitschrift fuer Polen“ 1936, s. 30

Zachęcający jest opis samego miasta, przez które przepływa niewielka rzeka dwoma strugami i wszystkie ulice są brukowane. Oprócz ogrodów, łąk i pastwisk, a także urodzajnej ziemi (,pierwszej klasy”) miasto posiada własny las.

${ }_{61}$ We wsi Kawęczynek z czasem włączonej w granice miasta.

${ }^{62}$ Mila polska obowiązywała w Królestwie Polskim do czasu wprowadzenia systemu metrycznego w 1918 r. Do 1819 r. mila polska liczyła ok. 7,15 km. 
Ogłoszenie informuje fabrykantów specjalizujących się w przerobie bawełny i lnu, iż w pobliżu cieków znajdą korzystne miejsca do bielenia tkanin, zaś sukienników zapewnia o możliwości znalezienia korzystnej lokalizacji dla prowadzenia produkcji i magazynowania wyrobów.

Ogłoszenie zawiera opis sytuacji demograficznej Szadku, w którym zamieszkiwało 1,5 tys. chrześcijan oraz 200 żydów. Nie podana została liczba osób wyznania ewangelickiego wśród chrześcijan, jednak zachętę dla potencjalnych osadników miała stanowić informacja, iż w mieście zamieszkują też rodziny niemieckie.

W mieście są trzy kościoły, z których jeden jak sugeruje anons mógłby zostać urządzony na ewangelicki. Działają też instytucje pełniące funkcje administracyjne i usługowe, w tym sąd okręgowy. W mieście siedzibę ma lekarz okręgowy, syndyk miejski, notariusz i urzędnicy sądowi. Z punktu widzenia gospodarki finansowej miasta istotne było posiadanie przez Szadek przywileju propinacji (wyłącznego prawa do produkcji i sprzedaży piwa, gorzałki i miodu), a dochody z dzierżawy tego przywileju w pełni zabezpieczały pokrycie podatków płaconych przez miasto.

Na uwagę zasługuje bogata infrastruktura gospodarcza miasta, które posiada młyn wodny z ,zapewnioną wodą”, sześć młynów wiatrowych i dwie tłocznie oleju „kompletnie wyposażone i w dobrym stanie”. Osadników do miasta ma przyciągnąć bogaty zestaw działalności gospodarczych, prowadzonych przez jego mieszkańców, którzy oprócz rolnictwa trudnią się rzemiosłem. Wśród rzemieślników jest 10 piekarzy, 10 masarzy, dwóch kotlarzy, czterech ślusarzy, czterech stolarzy, czterech kowali, czterech kołodziejów, a także osoby trudniące się świadczeniem innych usług, w tym przewozowych. Przyjezdni mogą się zatrzymać w jednej z czterech gospód znajdujących się w mieście, z których każda dysponuje stajnią dla koni. Zaopatrzenie w szeroki asortyment wyrobów zamiejscowych (także spożywczych) zapewniają m.in. działające w mieście cztery sklepy kolonialne, jeden handlujący farbami i kram (jak byśmy dziś powiedzieli sklep „wielobranżowy"). O randze ponadlokalnej funkcji handlowej Szadku świadczy też podana liczba 14 jarmarków odbywających się każdego roku oraz cotygodniowe targi.

Ważną część kierowanego do cudzoziemskich osadników ogłoszenia stanowiła informacja o oferowanych fabrykantom do zasiedlenia działkach. W mieście wydzielono 67 działek budowlanych o wielkości 40, 50, 60, 70 lub 80 prętów ${ }^{63}$ (tj. odpowiednio około 7,5, 9,3, 11,2, 13,1 lub 14,9 ara), przydzielanych w zależności od zamożności fabrykanta. Działki wraz z przypisanymi do nich ogrodami położone były na terenie nazwanym „Nowym Miastem”, na wschód od starej zabudowy miejskiej, z którą bezpośrednio sąsiadowały. W momencie ukazania się ogłoszenia na „Nowym Mieście” była już wybudowana gospoda i dwa nowe domy. Ponadto w starej części Szadku do sprzedaży było przeznaczonych sto

631 morga $=0,56$ ha $=300$ prętów; 1 pręt $=18,66 \mathrm{~m}^{2}$. 
działek z ogrodami (od których poza wykupem ziemi nie pobiera się podatku), a także 50 domów.

Istotnym uzupełnieniem informacji o możliwości nabycia działek było określenie warunków na jakich możliwe było uzyskanie materiałów budowlanych, przede wszystkim drewna i cegły. Ogłoszenie precyzowało, iż w lasach odległych od miasta $\mathrm{o} 1 / 4 \mathrm{i}^{1} / 2$ mili dostępne jest drewno budowlane w niskiej cenie. Cena sągu ${ }^{64}$ drewna miękkiego to 4 guldeny ${ }^{65} 6$ groszy, zaś drewna twardego - 5 guldenów 6 groszy, a dowóz jednego sągu drewna kosztuje 2 guldeny. Natomiast 1000 sztuk cegły kosztowało 20 guldenów, podobna była cena dachówki. Inne materiały budowlane (kamienie, glina i piasek) były dostępne bezpłatnie.

Końcowa część ogłoszenia informuje o wysokości opłat i czasowych zwolnieniach od nich. Osiedlającym się w Szadku fabrykantom (zarówno w nowej jak i starej części miasta) przysługiwało 6-letnie zwolnienie od wszelkich podatków. Po tym okresie opłata za posiadaną działkę wynosić miała 3 grosze od pręta powierzchni działki budowlanej i 1 grosz od pręta powierzchni ogrodu. Tekst zamyka zapewnienie o gotowości mieszkańców i władz Szadku do udzielenia osadnikom fabrycznym wszelkiej pomocy i niezbędnego wsparcia.

\section{UWAGI KOŃCOWE}

Lata 1815-1845 to okres przyspieszonego rozwoju ekonomicznego i industrializacji, głębokich przekształceń społecznych i zmian w strukturze osadniczej współczesnego regionu łódzkiego, do czego w zasadniczy sposób przyczynili się napływający przybysze z terenów niemieckich. Zaludniały się przybyszami zarówno wsie jak $i$ miasta, te ostatnie najwybitniej, w ogóle $w$ punktach, gdzie warunki miejscowe największe otwierały tym przybyszom widoki, lub gdzie dostęp do osiedlenia się najbardziej znajdowali ułatwiony [...] zlewali się oni zwolna z ludnościa miejscowa, przejmowali jej obyczaje i zamiłowanie do nowej swej ojczyzny; tącząc się zaś z nia związkami krwi wnosili do wielu rodzin polskich zalety $i$ wady, wlaściwe ich rasie, a rzesze migrantów byty przez dtugie czasy pożądanym dla krajów polskich nabytkiem, wzmacniaty jego sity ekonomiczne, bogacity kraj w ludność, $w$ zasoby, w sity produkcyjne i intelektualne ${ }^{66}$.

Okres Królestwa Polskiego [...] przynióst intensyfikację procesu migracji ludności niemieckiej. Można mówić o pewnym priorytecie, jaki w epoce konstytucyjnej

${ }^{64} \mathrm{~W}$ oryginalnym tekście ogłoszenia miara objętości określona jako „klafter” i najprawdopodobniej odpowiadająca nowopolskiej mierze objętości drewna w Królestwie Polskim równej ok. $2,58 \mathrm{~m}^{3}$.

${ }_{65}$ Gulden (inaczej złoty polski, lub floren) $=30$ groszy.

${ }^{66}$ H. Wierciński, Niemcy w Królestwie Polskim, „Biblioteka Warszawska” 1908, t. III, z. 2 , s. 209. 
Królestwa nadano polityce pozyskiwania dla kraju użytecznych cudzoziemców. Stużyto temu prawodawstwo, stwarzajace nie tylko bodźce, ale dajace też przybyszom gwarancje ochrony ich praw ${ }^{67}$. A ogólnie przyjazne warunki rozwoju ekonomicznego w Królestwie tłómacza zarówno to, że cudzoziemcy tak chętnie odpowiedzieli na wezwanie rzadu polskiego, jak i to, że powiodło im się w Polsce ${ }^{68}$.

Powyższe konstatacje trudno jednak odnieść do Szadku. Pomimo podejmowanych kolejnych działań zachęcających do osiedlenia w mieście znaczniejszy napływ cudzoziemskich rzemieślników nie następował. Ostatecznie próba przekształcenia Szadku w znaczący ośrodek przemysłowy nie powiodła się, a sprowadzone także kilka familii fabrykantów, nie będąc w stanie się utrzymać, do innych miast fabrycznych przeprowadzić się musiało ${ }^{69}$. Z powodu braku nowych osadników zainteresowanych podjęciem działalności rękodzielniczej opracowany w połowie lat 20. plan regulacji miasta w zakresie zabudowy i zasiedlenia wydzielonych na Nowym Mieście działek nie wszedł w życie ${ }^{70}$.

W latach 1810-1825 liczba ludności miasta wzrosła zaledwie z 1,1 tys. do 1,4 tys., przy niewielkim udziale mniejszości niemieckiej. W 1829 r. plan katastralny miasta dokumentował istnienie 325 siedlisk, zasiedlonych przez 1,5 tys. osób, w tym ponad dwustu Żydów i kilkanaście rodzin ewangelickich, a więc narodowości niemieckiej. W 1829 r. miała miejsce licytacja pustych placów, których właściciele (osadnicy, którym przekazano działki) w oznaczonym terminie nie wybudowali domów ${ }^{71}$. W 1857 r. w Szadek liczył niecałe 2,0 tys. mieszkańców, w tym 62 Niemców i 426 Żydów ${ }^{72}$. Z czasem w Szadku produkcja tekstylna całkiem zanikła - w $1856 \mathrm{r}$. w mieście zaledwie dwie osoby trudniły się sukiennictwem i farbiarstwem ${ }^{73}$, a w latach 60. XIX w. nie było już żadnego rzemieślnika zaangażowanego $\mathrm{w}$ produkcję tekstylną ${ }^{74}$.

Przyczyn niepowodzenia było wiele. W okresie lat 20. XIX w. obok fali napływu osadników z ziem niemieckich zaznaczył się przepływ niemieckojęzycz-

${ }^{67}$ D. Brandes, Von den Zaren adoptiert. Die duetschen Kolonisten und die Balkansiedler in Neurußland und Besarabien 1751-1914, München 1993 [za:] K. Woźniak, Niemieckie osadnictwo wiejskie między Prosna a Pilica i Wistą od lat 70. XVIII w. do 1866 roku. Proces i jego interpretacje, Łódź 2013, s. 17.

${ }_{68}$ L. Janowicz, Zarys rozwoju przemystu..., s. 20.

69 AGAD KSRW, sygn. 1787 [za:] M. Kulesza, Rozwój przestrzenny..., s. 66.

70 Z. Głąb, Szadek w świetle..., s. 100.

71 AGAD KWK sygn. 437 ulb. [za:] E. Hryniak, Studium historyczno-konserwatorskie..., s. 20.

72 L. Wolski, Materiaty do statystyki Królestwa Polskiego, „Kalendarz Astronomiczny Warszawski” 1860, s. 226-227. Inne źródła podają liczbę 1861 mieszkańców w 1859 r. Zob. AGAD KWK sygn. 1723, s. 108 [za:] E. Hryniak, Studium historyczno-konserwatorskie..., s. 22.

73 J. Goldberg, Studium historyczno-urbanistyczne..., s. 20.

74 A.J. Parczewski wymieniając rodzaje rzemiosła funkcjonujące w mieście w latach 60 . XIX w. nie wymienia ani jednego rzemieślnika z branży tekstylnej. Zob. A.J. Parczewski, Monografia Szadku, Warszawa 1870, s. 61. 
nych przybyszów między miastami i osadami przemysłowymi regionu. Część rzemieślników migrowała ze słabszych ośrodków do tych szybciej rozwijających się, a także do często oferujących lepsze warunki osiedlenia miast prywatnych. Zjawisko to dotknęło także Szadek, z którego fabrykanci przenosili się nie tylko do szybko rozwijającej się pobliskiej Zduńskiej Woli, ale także Pabianic i Zgierza ${ }^{75}$. Konkurencję stanowiły pobliski Łask i Sieradz, gdzie w latach 1823-1833 działała zatrudniająca ponad 1 tys. pracowników manufaktura sukiennicza A. Herrera ${ }^{76}$.

Także opublikowane w 1837 r. ogłoszenie nie miało większych szans przyczynienia się do ściągnięcia osadników niemieckich. Wprawdzie był to okres, w którym nadal liczny był napływ ludności niemieckiej na ziemie Królestwa Polskiego, ale wówczas już o wiele zdecydowanie atrakcyjniejszym miejscem prowadzenia działalności produkcyjnej były inne doskonale od dłuższego czasu prosperujące ośrodki regionu. Nowym przybyszom, zwłaszcza tym nie dysponującym znaczniejszym majątkiem, coraz trudniej było podjąć konkurencję w sektorze, w którym następowała koncentracja kapitału i produkcji.

Być może do niepowodzenia akcji osadniczej w Szadku w jakimś stopniu przyczynił się brak odpowiednich warunków środowiskowych. Jest to jednak o tyle mało prawdopodobne, że miasto otaczały lasy, a drewno i inne materiały budowlane były łatwo dostępne i tanie. Szadek dysponował również ciekami wodnymi, na których od dawna funkcjonowały młyny wodne, choć trudno stwierdzić czy i na ile odpowiadały one wymogom ówczesnej produkcji tekstylnej.

Pewne znaczenie mogły mieć też uwarunkowania społeczne i mało zachęcająca do osiedlenia atmosfera w mieście, które w drugim i trzecim dziesięcioleciu XIX w. było targane ciągłymi konfliktami mieszczan z ówczesnymi burmistrzami, oskarżanymi o pazerność, prywatę i przywłaszczanie pieniędzy należących do miasta $^{77}$. Na dodatek w $1831 \mathrm{r}$. Szadek dotknęła epidemia cholery.

XIX w. przyniósł nowe szanse rozwojowe wielu ośrodkom Polski Środkowej. Polityka rządu Królestwa Polskiego, kładąca nacisk na rozwój ekonomiczny ziem polskich i silnie wspierająca procesy industrializacji, stwarzała korzystne uwarunkowania ożywienia gospodarczego miast. Powstawały nowe miasta, a w starych wytyczano nowe dzielnice przemysłowe. Ośrodki, które wykorzystały pojawiającą się wówczas dobrą koniunkturę weszły na ścieżkę szybkiego rozwoju. Inne, nie dysponujące tak korzystnymi walorami lokalizacyjnymi, bądź odpowiednim potencjałem ludzkiej przedsiębiorczości, nie nadążały za ogólnym tempem procesów urbanizacyjnych i utrwalały swoje niekorzystne położenie. Do miast,

75 Por. G. Missalowa, Studia nad powstaniem łódzkiego okręgu przemysłowego (1815-1870), t. 1 Przemyst, Łódź 1964, s. 54 i 57.

76 J. Śmiałowski, Przemiany gospodarcze $w$ rolnictwie, rozwój miast i przemysłu $w$ latach zaborów, [w:] J. Śmiałowski (red.), Szkice z dziejów sieradzkiego, Łódź 1977, s. 199-200.

77 Do 1818 r. funkcję tę pełnił Budziszewski, a w kolejnych latach Michał Horodyski. Zob. T. Marszał, Szadek. Monografia miasta, Szadek 1995, s. 33. 
które ominęła szansa rozwoju związanego z procesami industrializacji należał Szadek $^{78}$, niegdyś ważny ośrodek życia społeczno-gospodarczego, a w drugiej połowie XIX w. uboga rolnicza mieścina, dzisiaj już tylko wiejska osada, ot, jak tyle innych miasteczek. Ludność spokojna, wytacznie prawie zajęta rolnictwem, rzadko słyszy zalatujące do niej echo ruchliwszego życia zamożniejszych miast okolicy [...]. A jednak bywało tu dawniej inaczej ${ }^{79}$.

\section{Bibliografia}

Badziak K., Woźniak K. (oprac.), Materiały do dziejów uprzemysłowienia Królestwa Polskiego. Raporty prezesów Komisji Województwa Kaliskiego z lat 1823-1832, Łódź 1998.

Bajer K., Przemyst włókienniczy na ziemiach polskich od poczatku XIX wieku do 1939 roku. Zarys historyczno-ekonomiczny, Łódź 1958.

Boss E., Sprawa robotnicza $w$ Królestwie Polskim $w$ okresie paskiewiczowskim 1831-1855, „Rozprawy Historyczne Towarzystwa Naukowego Warszawskiego” 1931, t. X, z. 1, s. 130-134.

Brandes D., Von den Zaren adoptiert. Die duetschen Kolonisten und die Balkansiedler in Neurußland und Besarabien 1751-1914, München 1993.

Flatt O., Opis miasta Łodzi pod względem historycznym, statystycznym i przemystowym, Warszawa 1853.

Friedman F., Poczatki przemystu w Łodzi 1823-1830, „Rocznik Łódzki” 1933, t. 3, s. $97-186$.

Gąsiorowska N., Osadnictwo fabryczne, ,Ekonomista” 1922, R. XXII, t. I, s. 1-40, t. II, s. 111-151, [w:] N. Gąsiorowska-Grabowska, Z dziejów przemystu w Królestwie Polskim, Warszawa 1965, s. 70-135.

Gąsiorowska N., Polska na przełomie życia gospodarczego 1764-1830, Warszawa 1947.

Gąsiorowska N., Sekcje fabryczne (1824-1835), „Ekonomista” 1916, R. XVI, t. I-II, s. 185-200, [w:] N. Gąsiorowska-Grabowska, Z dziejów przemystu w Królestwie Polskim, Warszawa 1965, s. 13-69.

Głąb Z., Szadek w świetle dziewiętnastowiecznych źródet kartograficznych, Wydział Filozoficzno-Historyczny, Uniwersytet Łódzki, Łódź 2005, praca magisterska, mpis.

Goldberg J., Studium historyczno-urbanistyczne Szadku, Łódź 1961, mpis.

Heike O., Aufbau und Entwicklung der Lodzer Textilindustrie. Eine Arbeit deutscher Einwarderer in Polen für Europa, Mönchengladbach 1971.

Hryniak E., Studium historyczno-konserwatorskie miasta Szadek, Kielce 1989, mpis. Janowicz L., Zarys rozwoju przemystu w Królestwie Polskim, Warszawa 1907.

\footnotetext{
78 T. Marszał, Szadek. Monografia miasta, Szadek 1995, s. 32.

79 A.J. Parczewski, Monografia Szadku, Warszawa 1870, s. 7.
} 
Jelonek A., Ludność miast i osiedli typu miejskiego na ziemiach Polski od 1820 do 1960, „Dokumentacja Geograficzna” 1967, z. 3/4.

Kessler W., Rola Niemców w Łodzi, [w:] K.A. Kuczyński, B. Ratecka (red.), Niemcy w dziejach Łodzi do 1945 r., Łódź 2001, s. 11-30.

Kieniewicz S., Przemiany społeczne i gospodarcze w Królestwie Polskim (1815-30), Warszawa 1951.

Kossman O., Deutsche in Polen: Siedlungsurkunden 16.-19. Jh., Heimatkreisgemeinschaft der Dt. aus dem Lodzer Industriegebiet, 1996.

Koszutski S., Rozwój ekonomiczny Królestwa Polskiego w ostatnim trzydziestoleciu 1870-1900, Warszawa 1905, s. 44.

Kulesza M., Rozwój przestrzenny $i$ współczesna struktura morfogenetyczna Szadku, „Biuletyn Szadkowski” 2003, t. 3, s. 55-71.

Lorentz Z., Raport prezesa Komisji Wojewódzkiej Mazowieckiej o stanie przemysłu włókienniczego w roku 1828, Odb. z rocznika Oddziału Łódzkiego Polskiego Towarzystwa Historycznego z 1929-1930, Łódź 1930.

Lorentz Z. (oprac.), Trzy raporty Rajmunda Rembielińskiego prezesa Komisji Województwa Mazowieckiego z objazdu obwodu łęczyckiego w 1820 r., „Rocznik Oddziału Łódzkiego Polskiego Towarzystwa Historycznego" 1928, t. 1.

Lück K., Deutsche Aufbaukräfte in der Entwicklung Polens, Plauen 1934.

Marszał T., Szadek. Monografia miasta, Szadek 1995.

Marszał T., Szadek jako ośrodek sukienniczy w XV-XVII w., „Biuletyn Szadkowski” 2014, t. 14, s. 39-58.

Meyer H. A., Alfred Laterman (1894-1945), „Zeitschrift für Ostforschung” 1951, nr 1, s. $423-425$.

Missalowa G., Studia nad powstaniem łódzkiego okręu przemysłowego (1815-1870), t. 1 Przemyst, Łódź 1964.

Missalowa G., Studia nad powstaniem łódzkiego okręgu przemysłowego (1815-1870), t. 2 Klasa robotnicza, Łódź 1967.

Missalowa G. (oprac.), Źródła do historii klasy robotniczej okręgu łódzkiego. Materiały do historii miast, przemystu i klasy robotniczej $w$ okręgu łódzkim, t. I, Warszawa 1957.

Ostrowski W., Świetna karta z dziejów planowania w Polsce 1815-1830, Warszawa 1949.

Parczewski A.J., Monografia Szadku, Warszawa 1870.

Piejko R., Biblioteka Uniwersytecka w Poznaniu w latach 1939-1945. Przyczynek do historii, „Biblioteka” 2007, nr 11(20) , s. 175-182.

Różański A., Próba określenia liczby imigrantów niemieckich przybytych na teren Królestwa, „Roczniki Dziejów Społecznych i Gospodarczych”, Poznań 1948, t. 10, s. $185-201$.

Rynkowska A., Działalność gospodarcza władz Królestwa Polskiego na terenie Łodzi przemysłowej w latach 1821-1831, ŁTN, Wydz. 2, nr 5, Łódź 1951. 
Stulczewski J., Ewangelicy w okolicy Szadku i Zduńskiej Woli w XIX-XX w., „Biuletyn Szadkowski" 2009, t. 9, s. 87-106.

Stulczewski J, Żydzi w Szadku - rys historyczny, „Biuletyn Szadkowski” 2010, t. 10, s. $141-160$.

Śmiałowski J., Przemiany gospodarcze w rolnictwie, rozwój miast i przemystu w latach zaborów, [w:] J. Śmiałowski (red.), Szkice z dziejów sieradzkiego, Łódź 1977, s. $199-230$.

Śmiałowski J., Zduńska Wola. Monografia miasta do 1914 r., Łódź 1974.

Warężak J., Raporty prezesa Komisji Województwa Mazowieckiego Rajmunda Rembielińskiego z lat 1823-1830, Warszawa 1939.

Wiech S., Ustawa o „Urządzeniu rzemiost, kunsztu i profesji” z 31 grudnia 1816 r. (próba oceny), „Kieleckie Studia Historyczne” 1994, t. 13, s. $29-41$.

Wierciński H., Niemcy w Królestwie Polskim, „Biblioteka Warszawska” 1908, t. III, z. 2. Wolski L., Materiały do statystyki Królestwa Polskiego, „Kalendarz Astronomiczny Warszawski" 1860, s. 226-227.

Woźniak K., Niemieckie osadnictwo wiejskie między Prosna a Pilica i Wisła od lat 70. XVIII w. do 1866 roku. Proces i jego interpretacje, Łódź 2013.

Wróbel E., Wróbel J., Aleksandrów Lódzki 1816-1831, „Mówią Wieki” 1988, nr 10, s. $15-19$.

Zbiór przepisów administracyjnych Królestwa Polskiego. Wydział spraw wewnętrznych i duchownych, cz. II Przemyst i zaktady przemyst positkujące, t. II, Warszawa 1866.

[Artykuł wpłynął: maj 2019; akceptacja: lipiec 2019]

\section{SZADEK AUTHORITIES' ADVERTISEMENT OF 1837 - MOTIVE FOR SOME REFLECTIONS ON GERMAN SETTLEMENT AND DEVELOPMENT OF TEXTILE MANUFACTURING IN SZADEK IN EARLY $19^{\mathrm{TH}}$ CENTURY}

\section{Summary}

In 1837, the authorities of Szadek published an announcement in German, advertising the city as a place favourable to industrial settlement. This advertisement was part of a wide-ranging action of the government of the Kingdom of Poland aimed at development of textile manufacturing in the Kingdom. Immigration of qualified workforce was seen as an important element of the planned development of the textile industry. The pro-immigration policy of the government resulted in the appearance on Polish territories of many new industrial settlements. Regrettably, Szadek - in $16^{\text {th }}$ century a leading centre of textile production - did not find itself among the towns which took advantage of the favourable situation entering the path of quick economic and demographic growth. 
The 1837 advertisement provides a description of Szadek at that time. But the result was disappointing and this town with impressive traditions became one of those settlements which experienced a long-lasting stagnation.

Keywords: Szadek, $19^{\text {th }}$ century, German settlement, industrialization, textile manufacturing 